\title{
ZA KONCEPT VSEŽIVLJENJSKEGA IZOBRAŽEVANJA IN VSEŽIVLJENJSKEGA UČENJA JE KONCEPT IZOBRAŽEVANJA ODRASLIH VITALNEGA POMENA
}

Sredi finančne krize se vse bolj izgublja spomin na to, kaj nam je Evropska unija dala doslej in nam daje zdaj, tudi na področju izobraževanja odraslih, zato je morebiti prav, da se vrnemo k preglednim vtisom s konference, ki je zaznamovala deseti rojstni dan programa Grundtvig. Konference Deset let programa Grundtvig ali deset let inovativnosti in inovacij v izobraževanju odrasli v Bruslju sem se resda udeležila kot predstavnica AGE Platform Europe, vodilne evropske organizacije za vprašanja starejših, kjer delujem kot izvedenka za zaposlovanje in izobraževanje starejših. Uradno sicer ne, v resnici pa sem na tej konferenci zagovarjala tudi stališča slovenske univerze za tretje življenjsko obdobje in seveda stališča, ki smo jih razvili v slovenski andragogiki.

\section{OD KOMENSKEGA DO GRUNDTVIGA}

Nedvomno vsi poznate programe Evropske komisije Leonardo da Vinci, Grundtvig, Erasmus, Comenius in druge ter veste, da ti dajejo okvire, v katerih potekajo evropski projekti na področju izobraževanja, morda pa malo manj teoretske okvire Evropske unije, v katere se ti programi vključujejo. V številnih programih v Evropi tečejo »transakcije in medsebojne kulturne, družbene, ekonomske in politične izmenjave, pa tudi vzajemno priznavanje «. ${ }^{1}$ Karl Deutsch, avtor transakcionalistične teorije, ene od teorij gradnje Evropske unije, trdi, da je občutek skupnosti med državami članicami odvisen od vzpostavitve mrež medsebojnih transakcij (glej opombo 1). In res! V Evropski uniji se vzpostavljajo mreže, takšne in drugačne; različni okvirni programi in podprogrami ter različne dejavnosti oziroma akcije nemalokrat podpirajo mreženje, projekte znotraj mrež, transakcije vseh vrst.

Kot je bilo načrtovano, je Evropa postala okvir za številne kulturne, družbene, ekonomske in druge transakcije med državami članicami in različnimi institucijami ter organizacijami. Še več, Jacques Delors trdi, da bo v prihodnosti »evropska dinamika veliko bolj odvisna od prispevka evropskih državljanov kot pa od prispevka evropskih institucij samih $\ll^{2} \mathrm{~V}$ ta namen je dobro, da se evropski državljani srečujejo in sodelujejo, da »bolje spoznajo Evropsko unijo, njene institucije in dosežke «. ${ }^{3}$ Ta misel se je zdaj začela pospešeno uresničevati in Evropska komisija prireja mnoge posvetovalne simpozije, na katere vabi izvedence, zagotavlja pa tudi stik po koncu posameznega simpozija.

Konferenca, ki sem se je udeležila, je bila posvečena pregledu dosežkov, ki so se nabrali v desetih letih, kar obstaja program Grundtvig za izobraževanje odraslih. 


\section{ŠTUDIJA O IZOBRAŽEVALCIH ODRASLIH}

Nizozemski inštitut Research voor Beleid je v sodelovanju z organizacijo PLATO (Univerza v Leidnu) predstavil študijo ALPINE o poklicu izobraževalca odraslih. Ključna vloga izobraževalcev odraslih je, da odraslim lajšajo pridobivanje znanja, veščin in zmožnosti. V posameznih evropskih državah so poskrbeli za raziskovanje tega poklica, načeloma tam, kjer ima študij andragogike dolgo tradicijo, drugod spet so stvari prepuščene naključju. Na evropski ravni pa je čutiti pomanjkanje vedenja o posameznih vidikih tega poklica. $\mathrm{Ne}$ ve se natanko, kdo so izobraževalci odraslih, kako se zaposlujejo, kakšne zmožnosti, veščine, kvalifikacije naj bi imeli, kakšen je njihov zaposlitveni položaj, kaj je njihova vloga in kaj so njihove naloge, kako poteka njihov poklicni razvoj, do kakšne mere je poklic privlačen in za koga. Zato je Evropska komisija naročila študijo o izobraževalcih odraslih po vsej Evropi z namenom, da pospeši poklicno rast izobraževalcev odraslih, pripravi akcijski načrt za učenje in izobraževanje izobraževalcev odraslih ter oblikuje politike. ${ }^{4}$

\section{KAKO SVETOVATI IZOBRAŽEVALCEM ODRASLIH IN KAKO SPREMLJATI NJIHOVO DELO}

Za svetovanje izobraževalcem odraslih ter spremljanje in nadzorovanje njihovega dela potrebujemo posebne spretnosti in znanje. Študija ALPINE razkriva, da so metode v izobraževanju odraslih nemalokrat še zmeraj metode formalnega izobraževanja in transmisije znanja. Izkazalo se je, da učna biografija in izobraževalna pot izobraževalcev odraslih še zmeraj nista povsem jasni. Le 26 odstotkov izobraževalcev odraslih se je posebej usposa- bljalo za svoje delo. Zaposlitvene možnosti izobraževalcev odraslih v nekaterih državah niso rožnate oziroma gre zvečine za občasno in pogodbeno zaposlitev. Prožno varnost bi veljalo spodbujati tudi na tem področju (alterniranje zaposlenosti z izobraževanjem, ki ga finančno podpira država). Organizacije, ki zaposlujejo izobraževalce odraslih, od slednjih pričakujejo poznavanje področja izobraževanja, da imajo poklicno izkustvo in da izkazujejo poznavanje posebnosti izobraževanja odraslih.

\section{PROGRAM GRUNDTVIG NEKOČ IN DANES}

Le zakaj tudi izobraževanje odraslih ne bi moglo biti vez med evropskimi narodi? Tako so se spraševali v EAEA, Evropskem združenju za izobraževanje odraslih, ki je v veliki meri spodbudilo nastanek programa Grundtvig. Razumljivo, saj je EAEA naslednik Mednarodnega biroja za izobraževanje odraslih, tam pa so negovali prepričanje, da lahko kultura in izobraževanje povežeta evropske narode tako, da vojne ne bo nikoli več. Ko je šlo za Grundtvig, v EAEA niso več razmišljali o tem, da se je treba postaviti po robu vojni, temveč predvsem o vsebinskem razvoju dejavnega evropskega državljanstva, o razvoju evropske transkulture, o vrednotah, kot so: pripadnost Evropi, medkulturno poznavanje, izboljševanje življenja Evropejcev. Program Grundtvig je namenjen razvoju neformalnega izobraževanja odraslih, zvečine izobraževanja za življenje, za različne socialne vloge, za dejavno državljanstvo vseh družbenih skupin.

Udeleženci konference, ki je predmet tega poročila, naj bi pridobili vpogled $\mathrm{v}$ desetletje inovativnosti in inovacij, ki so se sprožile pod vplivom programa Grundtvig. V obdobju, ko je bil Grundtvig še v povezavi s programom Socrates, je bilo veliko različnih možnosti. Nekatere 
dejavnosti (angl. actions) so vodile predvsem v razvoj novih vsebin, novih učnih pripomočkov, $v$ raziskovanje posameznih vprašanj na področju izobraževanja odraslih. To so bili zahtevnejši programi, ki so jih upravljale izbrane organizacije, te so urejale tudi finančne reči, skrbele so za potek projekta in za obsežno poročanje.

Najpreprostejši programi pa so bila tako imenovana učna partnerstva, kjer so se med seboj povezale najrazličnejše organizacije, pa tudi njihovi »študenti«, njihovo učno osebje in zaposleni. Današnja učna partnerstva imajo značilnosti nekdanjih, le da je njihovo delo dosti bolj načrtovano, da so cilji bolj ambiciozno zastavljeni, da mora vsakdo sam upravljati tudi finančna sredstva. Posebna skrb je bila nekoč namenjena temu, da partnerji prihajajo z vseh nebesnih strani Evrope, da so obeh spolov, da so med udeleženci osebe z invalidnostjo, da študenti prihajajo iz ciljnih skupin, ki so zajete $\mathrm{v}$ popisu prednostnih ciljev programa, itd. Danes je od vsega ostalo predvsem to učno partnerstvo, na novo pa se srečujemo z dejavnostjo GIVE, ki spodbuja prostovoljstvo (tudi na področju kulture) starejših evropskih državljanov. Prostovoljstvo kot učna in kulturna izkušnja starejših. Vrh tega potekajo razne Grundtvigove dejavnosti za usposabljanje in razvoj učnega osebja, Grundtvigove konference oziroma tečaji, opravljanje prakse za mlade diplomante izobraževanja odraslih, razmišlja se o podpori mrežam. Gre za internacionalizacijo ponudnikov izobraževanja odraslih, gre za mobilnost učnega osebja. Sprehoditi se po Evropi se zdi danes nujno za poklicni razvoj.

\section{UTRINKI IZ RAZMIŠLJANJ UDELEŽENCEV}

V središču vseh prizadevanj je bil razvoj metod, osredotočenih na tiste, ki se uči- jo, na njihove potrebe ter razvoj njihovih veščin in znanja.

Anne Sophie Parent iz Evropske platforme starejših (AGE) je v skupini, ki je razpravljala o izobraževanju starejših, poudarila, da enakost možnosti še zmeraj ne pomeni tudi družbene pravičnosti in da bi to morali imeti pred očmi v izobraževanju odraslih in starejših odraslih. Dobro bi morali poznati tudi družbene spremembe, denimo staranje prebivalstva ali migracije. V malo bolj patriarhalni Grčiji se ukvarjajo z vprašanjem, kako učitelje odraslih spremeniti v tiste, ki odraslim lajšajo njihovo izobraževanje. Učitelji si namreč ne želijo, da bi, tako mislijo, zgubili moč in oblast nad tistimi, ki se učijo, kar naj bi se zgodilo, če bi se iz učiteljev spremenili $v$ tiste, ki odraslim lajšajo njihovo učenje.

V Franciji so prepričani, da je o izobraževanju funkcionalno nepismenih in pojavu funkcionalne nepismenosti treba izobraziti vse: učitelje, tiste, ki se učijo, zaposlene v izobraževalni organizaciji. To prepričanje je mogoče posplošiti in bi moralo postati pravilo za vse, ki delujejo na področju izobraževanja odraslih. Poznati je treba kulturo svoje ciljne skupine in ne le izobraževalne programe.

$\mathrm{V}$ večjih belgijskih muzejih izobražujejo prostovoljne muzejske svetovalce, ki pomagajo muzejem v manjših krajih, da postavijo razstave in pripravijo druge dogodke. Tako so v okviru programa Grundtvig ti svetovalci pomagali pripraviti projekt, ki popisuje zgodovino neke tovarne, kajti lokalna skupnost vedenja o svoji tovarni ne želi zgubiti. Še več, v tovarni, njenih opuščenih prostorih, so organizirali niz dogodkov. Krajani se učijo pripovedovati zgodbe o tovarni in kraju. Prostovoljci so postavili gledališče in tudi njihove gledališke igre govorijo o tovarni, njeni rasti in življenju. 
Muzejski svetovalci se združujejo v $\boldsymbol{E M A C}$, European Museums Advisors Conference (slov. Evropska konferenca muzejskih svetovalcev), organizacijo, ki spremlja primere dobre prakse in podpira svetovalce.

GemTrex (angl. Gender workers in Europe: professionalisation, prospects and challenges) je projekt, ki je namenjen profesionalizaciji vzgoje izobraževalcev za vprašanja spola in spolnih vlog na delovnem mestu in drugod. Šlo je za študijo o tem, kako bi onemogočili reproduciranje stereotipov o obeh spolih, ne nazadnje tudi $\mathrm{v}$ izobraževanju odraslih. Izobraževalec za vprašanja spola je predvsem svetovalec. V programu je sodeloval tudi slovenski Mirovni inštitut in je prispeval svoje dobro teoretično poznavanje problematike. V projektu so obravnavali življenjske zgodbe žensk in moških.

EPAE, Pedagogy in Adult Education in Europe, je projekt, v katerem so partnerji ustvarili wiki prostor (www.ahs.wikispaces.net), kjer je mogoče pripovedovati o različnih metodah v elektronskem izobraževanju odraslih.

GINCO International Network Of Course Organisers je mednarodna mreža organizatorjev tečajev Grundtvig. Na koncu projekta je namreč mogoče pridobljeno znanje širiti v obliki evropskih tečajev. Organizacije, ki so pripravile takšne tečaje, pa so se kasneje združile v mrežo, da si medsebojno pomagajo in dosežejo standarde kakovosti.

\section{ZAKLJUČEK}

Eden največjih uspehov zadnjih desetih let je $\mathrm{v}$ tem, da se je okrepilo obče prepričanje o tem, kako pomembno je izobraževanje odraslih, kajti v nekaterih državah tega prepričanja pred tem ni bilo. Tako politika izobraževanja odraslih zdaj postaja ena glavnih politik v Strategiji do leta 2020, še posebej, kar zadeva mlajše odrasle, priseljence in starejše. Potrebujemo nadvse izobražene izobraževalce odraslih, prepričati moramo univerze, da delajo na področju izobraževanja odraslih. Potrebovali bi Grundtvig Mundus, nekaj takega, kot je že danes Erasmus Mundus. Izobraževanje odraslih pa je koncept vitalnega pomena sredi koncepta vseživljenjskega učenja.

\section{LITERATURA IN VIRI}

Balibar, E. (2003). We the People of Europe; reflections on transnational citizenship. Princeton: Princeton University Press.

Church, C. H., Phinnemor, D. (2009). The Penguin Guide to the European Treaties: From Rome to Maastricht, Amsterdam, Nice and Beyond. London: Penguin.

Findeisen, D. (2008). »Kompetence ali kultura izobraževalcev odraslih, to je zdaj vprašanje«. V: Đorđević, N. (ur.), Izobraževanje in usposabljanje učiteljev odraslih, Ljubljana.

Habermas, J. (2009). Europe The Faltering Project. Cambridge: Polity.

Intergenerational Solidarity For Cohesive And Sustainable Societes: Outcomes Of The Slovenian Presidency Conference. Brdo. Slovenia, 28.-29. april 2008. Dostopno na: http://www.mddsz.gov. si/fileadmin/mddsz.gov.si/pageuploads/dokumenti_pdf/solidarity_uk.pdf

Moussis, N. (2007). Guide to European Policies. Rixensart: European Study Service.

1 Dušana Findeisen v: Mi vsi smo Evropa. Priročnik za izobraževanje evropskih starejših dejavnih državljanov. Ur. Michael Schweiger. AESAEC, Auxilium, Graz 2009, v rokopisu.

2 Jacques Delors v oddaji radia France Culture: Les Controverses du progrès, junij 2009. 
3 Dušana Findeisen v: Mi vsi smo Evropa. Priročnik za izobraževanje evropskih starejših dejavnih državljanov. Ur. Michael Schweiger. AESAEC, Auxilium, Graz 2009, v rokopisu.

5 Glej ALPINE - Adult Learning Professions in Europe, A Study Of The Current Situation Trends And Issues, v rokopisu.

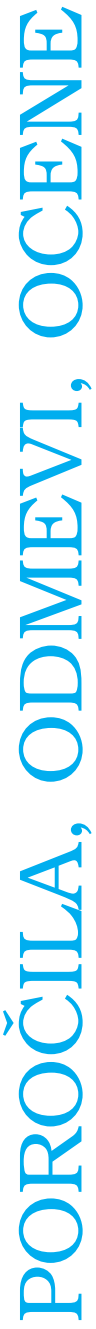

